\title{
PROBLEMS OF DEFORMATION BY LOCAL LOADING OF MULTILAYERED PLATES ON A RIGID FOUNDATION
}

\author{
Gurtovy O.G., PhD., Assistant Professor \\ o_g_gurtovy@ukr.net, ORCID: 0000-0002-2651-948X \\ Tynchuk S.O., PhD., Assistant Professor \\ s.o.tynchuk@nuwm.edu.ua, ORCID: 0000-0002-1763-8620 \\ Andrushkov V.I., PhD., Assistant Professor \\ v.i.andrushkov@nuwm.edu.ua, ORCID: 0000-0003-3365-4601 \\ National University of Water and Environmental Engineering
}

\begin{abstract}
In modern designs, multifunctional coatings with different stiffness and physicalmechanical characteristics of the layers are used. Multilayered coverings can be considered as thick plates resting on a rigid substrate. Refined models of symmetrical stress-strain state (SSS) have been used for studying the SSS of multilayered plates on a rigid foundation.

The design diagram of a transversely loaded plate is formed by symmetric supplementing it with regard to the contact surface and the foundation. The load to the double-thickness plate is applied bilaterally and symmetrically about its mid-surface. In such a way, only unflexible deformation can be modeled, which reduces the number of unknowns and the general order of differentiation of the calculating system of equations. Such a diagram models the frictionless slip of the plate over surface of its contact with the foundation. The rigid contact of the plate with the foundation is modelled by introducing an additional thin practically undeformed layer.

The refined continual models have been used to take into account the deformations of transverse shear and transverse compression in high iterative approximation. Two variants of refined models have been considered. In the first variant, the load function is given explicitly, whereas in the second variant it is replaced by an unknown desired function of compression.

Numerically, the models are realized by the variation-difference method (VDM). To derive the calculating system of algebraic equations of VDM, the Lagrange variation functional is integrated on a half-step of digitization, with a simultaneous use of backward and forward differences for the first derivative of displacement functions. The advantage of the second variant of the refined model has been demonstrated in the problems where the load function has gaps. The features of SSS plates on a rigid foundation under the action of local distributed loads have been presented.
\end{abstract}

Keywords: multilayered plate, a refined model, transverse shear, transverse compression, vibrational-difference method.

Introduction. The calculations for the strength and rigidity of various homogeneous and heterogeneous composite, especially multilayer, coatings are reduced to assessing their SSS as plates in contact with the foundation. It applies to the calculation of road multilayer clothing on sufficiently rigid bridges, tunnels, and other structures of transport structures, protective multilayer coatings of flat structural elements and parts, functional coatings of work surfaces of various equipment, etc. Therefore, the accurate determination of the SSS of multilayer plates on rigid foundations under the influence of stationary transverse loading, including local, is an urgent problem.

The combining of materials with isotropic and transversal-isotropic physical characteristics into a multilayer package allows creating of the multifunctional designs. The SSS of such structures due to their structural heterogeneity and the relatively low transverse stiffness of the individual layers is significantly associated with the effect of transverse shear deformations and transverse compression deformations. Therefore, the problem of refined modelling of SSS of plates, which would take into account these types of deformations, is urgent. It should be noted that the application of classical plate theory or refined shear models for SSS of transversely loaded plates on rigid foundation leads to a trivial zero solution. 
In $[1,2$, etc.], the refined models of SSS are considered, taking into account the transverse shear and transverse compression, oriented mainly to the description of flexural SSS, whereas the unflexible component of SSS prevails in plates on rigid foundation. Therefore, it is necessary to use a refined model that would accurately describe the unflexible component of the SSS of plate on rigid foundation.

In [3], the hypothesis was proposed and a special model of unflexible deformation of a homogeneous and layered plate was constructed, which, in combination with a model of flexible deformation, yields results close to an exact three-dimensional solution. In the tasks [4, 5], structural-continuous models of the SSS of transversely loaded plates are considered, and the accuracy and feasibility of approaches to modelling plate on rigid foundation on physical and geometrical parameters of the plate are investigated. In [6], the proposed models are applied for the estimation of the SSS plates with defects.

The purpose of the article. The purpose of the research is to show the features of the SSS plates on the rigid foundation under local load action using refined modelling with the application of approaches [3-5].

Materials and methods of research. The deformation of a rectangular multilayer plate, which rests on a rigid foundation in the linearly elastic statement is considered. The layers of plate are isotropic and transversely isotropic of arbitrary but constant thickness. Instead of the actual construction of the multilayer plate (Fig. 1a), it is suggested to consider the design diagram of the plate, which is formed by supplementing it with a symmetric one about the contact surface of the foundation. In this case, the plate will be symmetrically loaded with respect to the middle surface of the plate, and the thickness of the plate will double $H=2 b_{n}$ (Fig. 1b). The contact of the plate with the foundation is identical to the conditions of shear without friction (Fig. 1b). The rigid contact of the plate with the foundation is modelled by introducing an additional absolutely rigid thin interlayer of thickness $h_{0}$ (Fig. 1c).

Rigid contact conditions without slipping are maintained between the layers of the plate. However, other conditions of interlayer contact can be considered without changes in the formulation of the problem by introducing thin layers of low relative rigidity.

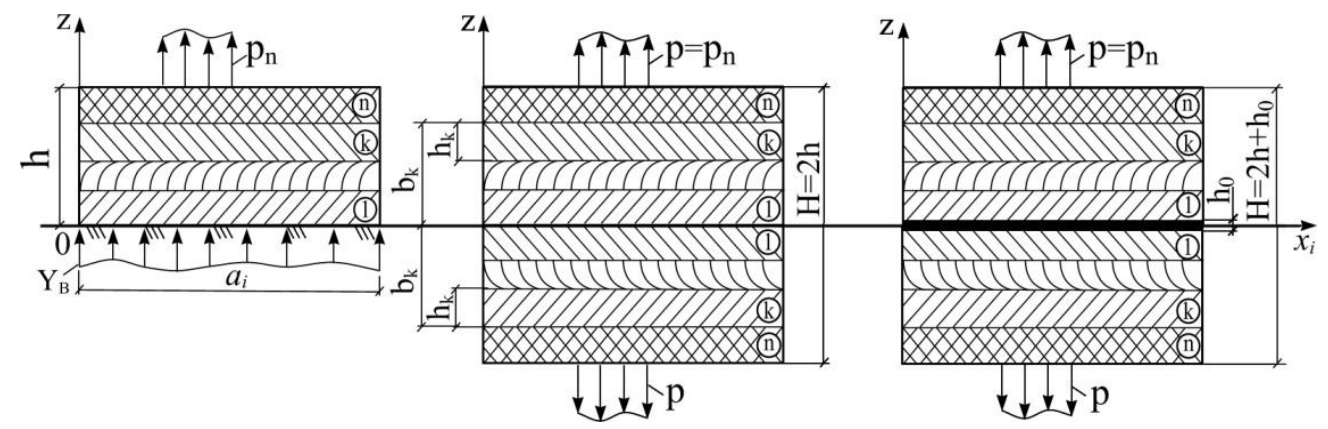

a)

b)

c)

Fig. 1. Optimization of the design diagram of a plate:

$a$ - multilayer plate on a rigid foundation; $b$ - symmetrical plate with sliding contact with the foundation; $\mathrm{c}$ - symmetrical plate with absolutely rigid contact with the foundation

This approach allows optimizing the refined SSS model of a plate considered in [3], which consisted of two qualitatively different SSS models, the flexural and unflexible ones. The flexible component of the SSS disappears because the SSS in the symmetric plate structure under bilateral symmetrical loading is completely described by the unflexible SSS. As a result, the number of unknown functions and, consequently, the order of differentiation of the resolving system of equations in the problem decrease significantly.

In a continual model [4], the components of the vector of normal $u_{3}^{(k)}$ and tangential $u_{i}^{(k)}$ displacements to the coordinate surface $x_{1} 0 x_{2}$ (Fig. 1) are represented by the sums of the products of the hypothetically specified power functions $\psi_{t}^{(k)}, \psi_{i r}^{(k)}$ of the transverse coordinate $z$ 
and the sought-for functions $\gamma_{t}, \beta_{i r}$ and $v_{i}$ of the coordinate surface $x_{1} 0 x_{2}$ :

$$
\begin{gathered}
u_{3}^{(k)}=\psi_{3 t, 3}^{(k)}(z) \gamma_{t}+\psi_{33,3}^{(k)}(z) p ; \quad t=\overline{1,2} ; \quad i=\overline{1,2} ; \\
u_{i}^{(k)}=v_{i}-\psi_{3 t}^{(k)}(z) \gamma_{t},_{i}-\psi_{33}^{(k)}(z) p,_{i}-\psi_{i r}^{(k)}(z) \beta_{i r} ; \quad r=\overline{1,4},
\end{gathered}
$$

where two functions $\gamma_{t}$ model the influence of transverse compression, and eight functions $\beta_{i r}$ shows the influence of transverse displacement in the fourth approximation for each variable $x_{i} ; p$ is the function of the given transverse load. Hereafter, the differentiation by $x_{\alpha}$ subscripts after the comma is performed. The summation with respect to repeating subscripts is also performed.

The model (1) is convenient in those problems where the load function $p\left(x_{i}\right)$ has no first and second kind breaks and thus does not contradict the principle of continuity of displacements $u_{\alpha}^{(k)}$ and the principle of differentiation of functions. Model (1) is very effective in analytical methods of calculation [4]. However, it must be replaced for problems where the load function has breaks $p\left(x_{i}\right)$ in (1) by an unknown compression function. Thus, the model is further implemented in the form of:

$$
\begin{gathered}
u_{3}^{(k)}=\psi_{3 t, 3}^{(k)}(z) \gamma_{t} ; \quad t=\overline{1,3} ; \\
u_{i}^{(k)}=v_{i}-\psi_{3 t}^{(k)}(z) \gamma_{t}, \psi_{i r}-\psi_{i r}^{(k)}(z) \beta_{i r} .
\end{gathered}
$$

The sought-for function $\gamma_{3}\left(x_{i}\right)$ is smooth and meets the conditions of continuity as well as functions $v_{i}, \gamma_{1}, \gamma_{2}, \beta_{i r}$.

Functions $\psi_{3 t}^{(k)}, \psi_{i r}^{(k)}$ that model the displacements distribution of $\mathrm{z}$ coordinate have the form [4]:

$$
\begin{gathered}
\psi_{3 t, 3}^{(k)}=\int_{0}^{z} a_{3333}^{(s)} F_{t}^{(s)} d z ; \quad \psi_{33,3}^{(k)}=\int_{0}^{z} a_{3333}^{(s)} d z ; \quad t=\overline{1,2} ; \quad r=\overline{1,4} ; \\
\psi_{i r}^{(k)}=-\int_{0}^{z} a_{i 3 i 3}^{(s)} f_{i r}^{(s)} d z ; \quad \psi_{l}^{(k)}=\int_{0}^{z} \psi_{l, 3}^{(s)} d z ; \quad s=\overline{1, k} ; \quad l=\overline{1,3} .
\end{gathered}
$$

In expressions (3), the functions $F_{t}^{(k)}(z)$ approximate the distribution of the stresses of transverse compression $\sigma_{33}$, and the functions $f_{i r}^{(k)}(z)$ approximate the stresses of transverse shear $\sigma_{i 3}$ across the plate thickness. They are described in detail in [4].

The resolving system of equations for models (1) and (2) by the variation-difference method (VDM) was obtained directly from the condition of minimum variation of the potential strain energy. The Lagrange variation principle is applied here:

$$
\delta U=\delta \Pi-\delta H=0,
$$

which in the case of flat deformation of multilayer plates is as follows:

$$
\delta U=\sum_{j=1}^{N} \iint_{S_{i}}\left\{\int_{-h}^{h}\left[\sigma_{11} \cdot \delta \varepsilon_{11}+\sigma_{13} \cdot \delta \varepsilon_{13}+\sigma_{33} \cdot \delta \varepsilon_{33}\right] d z-p\left(2 \bar{\psi}_{3 t, 3}^{(n)}\right) \cdot \delta \gamma_{t}\right\}_{j} d S_{j}=0
$$

where $\bar{\psi}_{3 t, 3}^{(n)}$ is the value of the function $\psi_{3 t, 3}^{(n)}$ at $z=h$ (Fig. 1b) or $z=h+0,5 h_{0}$ (Fig. 1c) for points on the surface of the plate.

Using (5) a discrete representation through finite differences of relative deformations $\varepsilon_{\alpha \beta}$ obtained from (1) by Cauchy relations and stresses $\sigma_{\alpha \beta}$ obtained by the Hooke`s law, we obtain of the resolving system of algebraic equations with respect to the nodal values of unknown functions $v_{i}, \gamma_{t}, \beta_{i r}$ of model (1).

Here, an approach is implemented in which the integration of the variation of the full energy functional (5) is performed in a step $\lambda / 2$ (Fig. 2), while using both the left (left of the node) and right (to the right of the node) differences for the first derivatives of the unknown functions. 


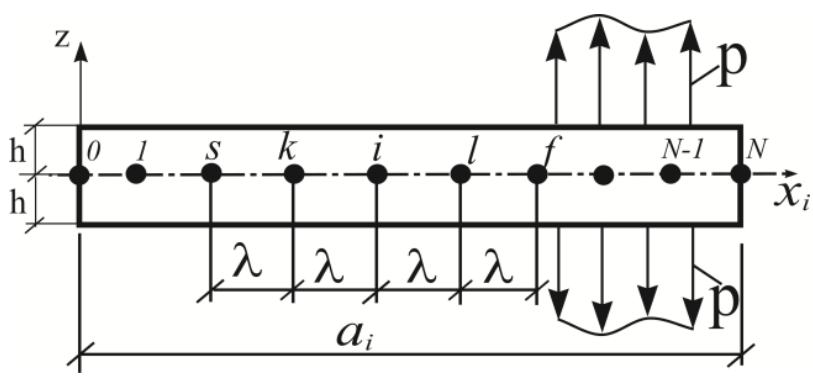

Fig. 2. Discrete design diagram of a plate in the VDM problems

Using the proposed approach with left and right differences to the functions $v_{1}$ and $\beta_{1 r}$ of model (1) in the functional (5), for the problem of flat plate deformation allowed obtaining the resolving equations of VDM for the node in the following form (if the numbering of nodes in Fig. 2):

a) for multipliers in variation $v_{i 1}$ in the node $i$ of displacement function $v_{1}$ in the plane of the coordinate surface $x_{1} 0 x_{2}$ :

$$
\begin{gathered}
B_{0}\left(-v_{k}+2 v_{i}-v_{l}\right)_{1} / \lambda-B_{3 t}\left(0,5 \gamma_{s}-\gamma_{k}+\gamma_{l}-0,5 \gamma_{f}\right)_{t} / \lambda^{2}- \\
\quad-B_{1 r}\left(-\beta_{k}+2 \beta_{i}-\beta_{l}\right)_{r} / \lambda+P_{t}\left(\gamma_{k}-\gamma_{l}\right)_{t} / 2=0 ;
\end{gathered}
$$

b) for multipliers in variation $\gamma_{i t}$ of transverse compression function $\gamma_{t}$ :

$$
\begin{aligned}
& -B_{3 t}\left(0,5 v_{s}-v_{k}+v_{l}-0,5 v_{f}\right)_{1} / \lambda^{2}+D_{q t}^{33}\left(\gamma_{s}-4 \gamma_{k}+6 \gamma_{i}-4 \gamma_{l}+\gamma_{f}\right)_{t} / \lambda^{3}- \\
- & H_{q t}^{3}\left(\gamma_{k}-2 \gamma_{i}+\gamma_{l}\right)_{t} / \lambda+D_{r t}^{13}\left(0,5 \beta_{s}-\beta_{k}+\beta_{l}-0,5 \beta_{f}\right)_{1} / \lambda^{2}+P_{t}\left(v_{k}-v_{l}\right)_{1} / 2- \\
& -J_{r t}^{1}\left(\beta_{k}-\beta_{l}\right)_{1 r} / 2-J_{q t}^{3}\left(\gamma_{k}-2 \gamma_{i}+\gamma_{l}\right)_{t} / \lambda+R_{q t} \gamma_{i t} \lambda-p_{i}\left(2 \bar{\psi}_{3 t, 3}^{(n)}\right) \gamma_{i t} \lambda=0 ;
\end{aligned}
$$

c) for multipliers in variation $\beta_{i 1 r}$ of transverse shear function $\beta_{1 r}$ :

$$
\begin{aligned}
- & B_{1 r}\left(-v_{k}+2 v_{i}-v_{l}\right)_{1} / \lambda+D_{t r}^{31}\left(0,5 \gamma_{s}-\gamma_{k}+\gamma_{l}-0,5 \gamma_{f}\right)_{t} / \lambda^{2}+ \\
& +D_{g r}^{11}\left(-\beta_{k}+2 \beta_{i}-\beta_{l}\right)_{1 r} / \lambda-H_{t r}^{1}\left(\gamma_{k}-\gamma_{l}\right)_{t} / 2+T_{g r} \beta_{i 1 r} \lambda=0 .
\end{aligned}
$$

The constant coefficients in the system of resolving equations (6) - (8) are the following generalized physical-geometrical characteristics of the plate and are determined similarly to the coefficients of the resolving system of differential equations with $[3,4]$ as follows:

$$
\begin{gathered}
B_{0}=\int_{-b_{n}}^{b_{n}} A_{1111} d z ; \quad B_{\varphi s}=\int_{-b_{n}}^{b_{n}} A_{111} \psi_{\varphi s} d z ; \quad P_{t}=\int_{-b_{n}}^{b_{n}} A_{1133} \psi_{3 t,} d z ; \quad s, f=\overline{1,4} ; \\
D_{f s}^{\varphi \mu}=\int_{-b_{n}}^{b_{n}} A_{1111} \psi_{\varphi f} \psi_{\mu s} d z ; \quad J_{f t}^{\varphi}=\int_{-b_{n}}^{b_{n}} A_{1133} \psi_{\varphi f} \psi_{3 t,} d z ; \quad H_{t s}^{\varphi}=\int_{-b_{n}}^{b_{n}} A_{1133} \psi_{3 t,} \psi_{33} \psi_{\varphi s} d z ; \\
R_{t q}=\int_{-b_{n}}^{b_{n}} A_{3333} \psi_{3 t,{ }_{33}} \psi_{3 q,} d z ; \quad T_{r g}=\int_{-b_{n}}^{b_{n}} G^{\prime} \psi_{1 r_{3}, \psi_{1 g, 3}} d z ; \varphi, \mu=1,3 ; \quad t, q=\overline{1,3} ; \quad r, g=\overline{1,4},
\end{gathered}
$$

where $A_{\alpha \beta \gamma \delta}$ are the coefficients of Hooke's law $\sigma_{\alpha \beta}=A_{\alpha \beta \gamma \delta} e_{\gamma \delta} ; G^{\prime}$ is module of shear in the layer; $b_{n}$ is coordinate $z$ of the upper surface of the plate.

Research results. When acting on a plate local load with a function $p\left(x_{i}\right)$ having a firstorder breaks, the accuracy of the models $\mathrm{M}_{1}(1)$ and $\mathrm{M}_{2}$ (2) was compared (Table 1) on the example of the calculation of displacements in a homogeneous thick plate $(v=0,25 ; a / h=4 ; a / H=2)$ by VDM at $\lambda=a / 80$. Evenly distributed load $p$ acts on a limited area $-5 \lambda \leq x_{1} \leq 5 \lambda$ at the nodes $i=\overline{0,5}$. The diagram is given on half of the plate $0 \leq x_{1} \leq a / 2$ (Fig. 3). 
Table 1 - Value of Displacement $u_{\alpha}^{\#}=u_{\alpha} E / p_{0} h$ in the Plate at a Local Load

\begin{tabular}{|c|c|c|c|c|c|c|c|c|c|c|}
\hline \multirow{3}{*}{\multicolumn{2}{|c|}{$\begin{array}{c}\text { Displacements } \\
\text { Solution } \\
\text { Models } \\
\end{array}$}} & \multicolumn{3}{|c|}{$-10 u_{3}^{\#}$ at $z=h$} & \multicolumn{3}{|c|}{$10 u_{1}^{\#}$ at $z=h$} & \multicolumn{3}{|c|}{$10 u_{1}^{\#}$ at $z=0$} \\
\hline & & \multicolumn{2}{|c|}{ VDM } & \multirow{2}{*}{$\begin{array}{c}\text { FEM } \\
\text { (SCAD) }\end{array}$} & \multicolumn{2}{|c|}{ VDM } & \multirow{2}{*}{$\begin{array}{c}\text { FEM } \\
\text { (SCAD) }\end{array}$} & \multicolumn{2}{|c|}{ VDM } & \multirow{2}{*}{$\begin{array}{c}\text { FEM } \\
\text { (SCAD) }\end{array}$} \\
\hline & & $\mathrm{M}_{1}$ & $\mathrm{M}_{2}$ & & $\mathrm{M}_{1}$ & $\mathrm{M}_{2}$ & & $\mathrm{M}_{1}$ & $\mathrm{M}_{2}$ & \\
\hline \multirow{6}{*}{ 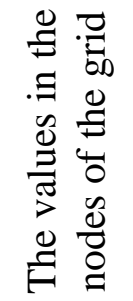 } & 0 & 6,55 & 6,39 & 6,42 & 0 & 0 & 0 & 0 & 0 & 0 \\
\hline & 1 & 6,50 & 6,32 & 6,37 & $-0,13$ & $-0,20$ & $-0,19$ & 0,11 & 0,12 & 0,13 \\
\hline & 4 & 5,75 & 5,21 & 5,52 & $-0,36$ & $-0,77$ & $-0,76$ & 0,4 & 0,49 & 0,50 \\
\hline & 5 & 5,40 & 4,59 & 4,90 & $-1,46$ & $-0,88$ & $-0,93$ & 0,79 & 0,60 & 0,61 \\
\hline & 6 & 3,35 & 3,90 & 3,62 & $-1,49$ & $-0,91$ & $-0,97$ & 0,90 & 0,70 & 0,71 \\
\hline & 7 & 2,95 & 3,24 & 2,96 & $-0,46$ & $-0,86$ & $-0,88$ & 0,75 & 0,80 & 0,81 \\
\hline
\end{tabular}

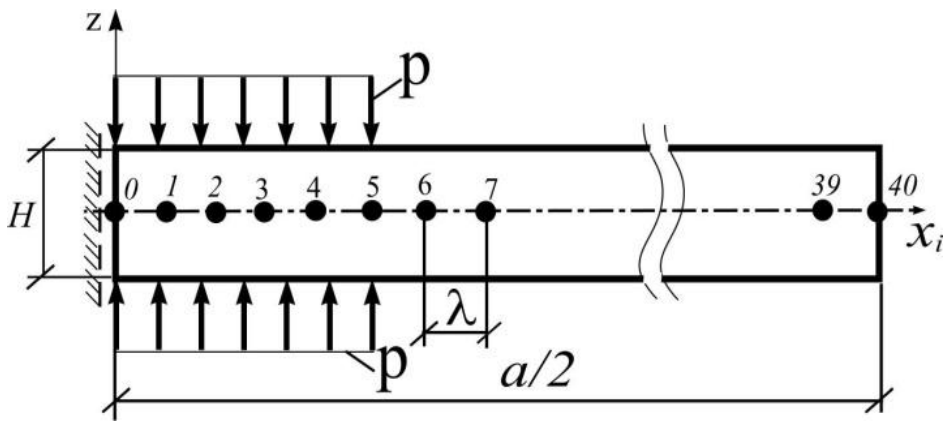

Fig. 3. Design diagram of the plate under localized load

It can be seen that in the field of load change $p$ (nodes 5-7 in VDM), the results of the $\mathrm{M}_{2}(2)$ model are much better than those of $\mathrm{M}_{1}(1)$, and are consistent of results of finite element method (FEM) calculated by the complex "SCAD". The displacements obtained by $\mathrm{M}_{1}$ in nodes 4, 5, 6 contain "jumps" of the values of the displacement functions, which are not presented in the results for $\mathrm{M}_{2}$ and SCAD. At other nodes the values of displacements in the solving by $\mathrm{M}_{1}, \mathrm{M}_{2}$, and SCAD are close. Therefore, the use of the $\mathrm{M}_{2}$ model in which hypothesized for $u_{\alpha}^{(k)}$ have not of given load function $p$, is more appropriate than the $\mathrm{M}_{1}$ model (1). Note that in this problem, the number of unknowns in the system of equations of FEM for SCAD equals to $n=40 \times 18 \times 2=1440$, and $n=40 \times 6=240$ for VDM. Moreover, when calculating the flat problem of a multilayer plate according to FEMs with rectangular FE, the number of unknowns in the presence of especially thin layers can significantly increase, whereas the number of equations in system (6) - (8) and the number of unknowns is independent on the number of layers by models (1) and (2).

The influence on the SSS of plates of different nature of loading on a plate on a rigid foundation with gripped edges was investigated (Table 2).

Three cases of action of uniformly distributed load are considered: $1 ; 4$ - throughout the length of the plate; $2 ; 5$ - half the length in the middle of a plate; $3 ; 6$ - half-length at the edges of a plate. The contact of plates with a rigid foundation is sliding and the edges of the plate are rigidly gripped. In variants 1,2 and 3 (Table 2) a single-layer transversely isotropic plate with $E=2 \cdot 10^{5} \mathrm{MPa}$; $E^{\prime}=2 \cdot 10^{4} \mathrm{MPa}\left(E / E^{\prime}=10\right) ; v=0,25 ; v^{\prime}=0,01$ was considered. For diagrams 4, 5 and 6, a twolayer plate with transversely isotropic layers $\left(E^{(k)} / E^{(k)}=10\right)$ of equal thickness $h_{1}=h_{2}=0,5 h$ with characteristics: $E^{(1)}=1 \cdot 10^{4} \mathrm{MPa} ; E^{(2)}=2 \cdot 10^{5} \mathrm{MPa} ; v^{(1)}=v^{(2)}=0,25 ; v^{\prime(1)}=v^{\prime(2)}=0,01$. In the calculation the design diagrams of plates are formed by symmetric supplementing it with regard to the contact surface and the foundation $(a / h=4 a / H=2)$ have been used.

It is shown (Table 2) that in homogeneous plate at discrete load (variants 2 and 3) relative transverse displacement $u_{3}^{\#}=u_{3} E / p h$ reduced compared to the variant 1 . The relative displacements 
Table 2 - Displacement and Stress in Plates $(a / h=4)$ with Rigidly Gripped Edges

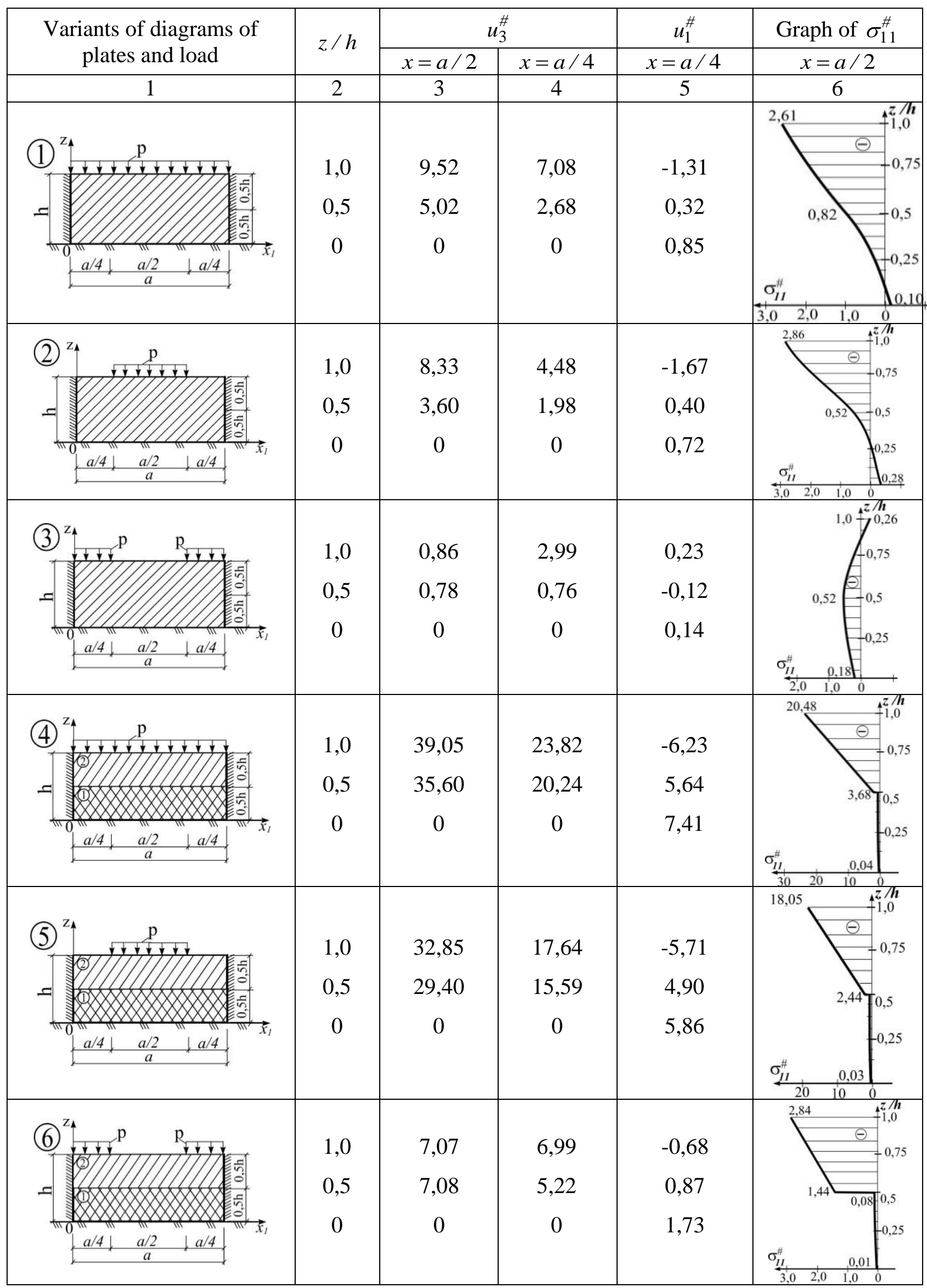


$u_{\alpha}^{\#}=u_{\alpha} E^{(2)} / p h$ increase five times in the presence of a weaker lower layer (variants 4; 5 and 6), and almost ten times the relative stresses $\sigma_{11}^{\#}=\sigma_{11} / p$ increase in comparison with the SSS of a homogeneous plate in the two-layer slab.

Conclusion. Therefore, the feasibility of using refined models in the estimation of the SSS of multilayer coatings on a rigid foundation under a local load has been demonstrated. It is shown that the use of the model $\mathrm{M}_{2}$, which does not contain in hypotheses for displacements of the function of a given load, is more appropriate than the model $\mathbf{M}_{1}$ with a given function of the load. The peculiarities of the SSS of plates and the nature of the distribution of displacements and stresses in the plates at different types of distributed, including localized, loads are revealed.

\title{
References
}

[1] V.G. Piskunov, "Ob odnom variante neklassicheskoi teorii mnogosloinykh pologikh obolochek i plastin”, Prikladnaia mekhanika, Vol. 15, 11, pp. 76-81, 1979.

[2] A.O. Rasskazov, "K teorii mnogosloinykh ortotropnykh pologikh obolochek", Prikladnaia mekhanika, Vol. 12, 11, pp. 50-56, 1976.

[3] A.G. Gurtovyi, "Vysokotochnoe modelirovanie deformirovaniia sloistykh struktur", Mekhanika kompozitnykh materialov, Vol. 35, 1, pp. 13-28, 1999.

[4] A.G. Gurtovyi, \& S.A. Tynchuk, "Bezyzgibnaia utochnennaia model' deformirovaniia mnogosloinykh plyt na nedeformiruemom osnovanii", Mekhanika kompozitnykh materialov, Vol. 42, 5, pp. 643-654, 2006.

[5] O.G. Gurtovyj, S.O. Tynchuk, \& L.S. Ugryn, "Vykorystannja utochnenyh modelej u zadachah rozrahunku NDS plyt na zhorstkij osnovi ta oblast' utochnen", Zbirnyk "Naukovi zapysky", Ukrai'ns'ka akademija drukarstva, Vol. 1(54), pp. 52-59, 2017.

[6] A.G. Gurtovyi, S.A. Tynchuk, \& D.V. Zhuk, "Deformirovanie odnorodnykh i mnogosloinykh pokrytii s prodolnymi defektami na zhestkom osnovanii”, Mekhanika kompozitnykh materialov, Vol. 52, 2, pp. 275-290, 2016.

\section{ЗАДАЧІ ДЕФОРМУВАННЯ ЛОКАЛЬНИМ НАВАНТАЖЕННЯМ БАГАТОШАРОВИХ ПОКРИТТІВ НА ЖОРСТКІЙ ОСНОВІ}

\author{
Гуртовий О.Г., к.Т.н., доцент, \\ o_g_gurtovy@ukr.net, ORCID: 0000-0002-2651-948X \\ Тинчук С.О., к.т.н., доцент, \\ s.o.tynchuk@nuwm.edu.ua, ORCID: 0000-0002-1763-8620 \\ Андрушков B.I., к.т.н., доцент, \\ v.i.andrushkov@nuwm.edu.ua, ORCID:0000-0003-3365-4601 \\ Національний університет водного господарства та природокористування
}

Анотація. У сучасних конструкціях застосовуються багатофункціональні покриття 3 різною жорсткістю і фізико-механічними характеристиками шарів. Багатошарові покриття можна розглядати як товсті плити, що опираються на жорстку підкладку. Для дослідження напружено-деформованого стану (НДС) багатошарових покриттів на жорсткій основі застосовано уточнені моделі симетричного НДС.

Розрахункова схема поперечно навантаженої плити утворюється симетричною добудовою плити відносно поверхні контакту її з основою. Навантаження на таку плиту подвійної товщини прикладається двосторонньо симетрично щодо ії серединної поверхні. Це дозволяє моделювати тільки беззгинове деформування, що зменшує кількість невідомих та загальний порядок диференціювання розрахункової системи рівнянь. Дана схема моделює проковзування без тертя на поверхні контакту плити з основою. Жорсткий контакт плити з основою моделюється введенням додаткового тонкого шару, який практично не деформується. 
Використано уточнені континуальні моделі, які враховують деформації поперечного зсуву та поперечного обтиснення в високих ітераційних наближень. Розглянуто два варіанти уточнених моделей. У першому варіанті функція навантаження задана явно, а в другому варіанті вона замінена невідомою шуканою функцією обтиснення.

Чисельно моделі реалізовані варіаційно-різницевим методом (ВРМ). Для отримання розрахункової системи алгебраїчних рівнянь ВРМ застосовано інтегрування варіаційного функціоналу Лагранжа на половині кроку дискретизації з одночасним використанням лівих і правих різниць для перших похідних від функцій зсуву. Продемонстровані переваги другого варіанту уточненої моделі в задачах, де функція навантаження має розриви. Показано особливості НДС плит на жорсткій основі при дії локального навантаження.

Ключові слова: багатошарова плита, уточнена модель, поперечний зсув, поперечне обтиснення, варіаційно-різницевий метод.

\title{
ЗАДАЧИ ДЕФОРМИРОВАНИЯ ЛОКАЛЬНОЙ НАГРУЗКОЙ МНОГОСЛОЙНЫХ ПОКРЫТИЙ НА ЖЕСТКОМ ОСНОВАНИИ
}

\author{
Гуртовый А.Г., к.т.н., доцент, \\ o_g_gurtovy@ukr.net, ORCID: 0000-0002-2651-948X \\ Тынчук С.А., к.т.н., доцент, \\ s.o.tynchuk@nuwm.edu.ua, ORCID: 0000-0002-1763-8620 \\ Андрушков В.И., к.т.н., доцент, \\ v.i.andrushkov@nuwm.edu.ua, ORCID:0000-0003-3365-4601 \\ Национальньий университет водного хозяйства и природопользования
}

\begin{abstract}
Аннотация. В современных конструкциях применяются многофункциональные покрытия с различной жесткостью и физико-механическими характеристиками слоев. Многослойные покрытия можно рассматривать как толстые плиты, опирающиеся на жесткую подложку. Для исследования напряженно-деформированного состояния (НДС) многослойных покрытий на жестком основании применены уточненные модели симметричного НДС.

Расчетная схема поперечно нагруженной плиты образуется симметричной достройкой плиты относительно поверхности контакта ее с основанием. Нагрузка на такую плиту двойной толщины прикладывается двусторонне симметрично относительно ее срединной поверхности. Это позволяет моделировать только безизгибное деформирование, что уменьшает количество неизвестных и общий порядок дифференцирования расчетной системы уравнений. Данная схема моделирует смещение без трения на поверхности контакта плиты с основанием. Жесткий контакт плиты с основанием моделируется введением дополнительного тонкого, но практически недеформируемого слоя.

Использованы уточненные континуальные модели, которые учитывают деформации поперечного сдвига и поперечного обжатия в высоких итерационных приближениях. Рассмотрены два варианта уточненных моделей. В первом варианте функция нагрузки задана явно, а во втором варианте она заменена неизвестной искомой функцией обжатия.

Численно модели реализованы вариационно-разностным методом (ВРМ). Для получения расчетной системы алгебраических уравнений ВРМ применено интегрирование вариационного функционала Лагранжа на пол шаге дискретизации с одновременным использованием левых и правых разностей для первых производных от функций смещения. Продемонстрированы преимущества второго варианта уточненной модели в задачах, где функция нагрузки имеет разрывы. Показаны особенности НДС плит на жестком основании при воздействии локальной распределенной нагрузки.
\end{abstract}

Ключевые слова: многослойная плита, уточненная модель, поперечный сдвиг, поперечное обжатие, вариационно-разностный метод. 